\title{
PERWUJUDAN DAN IMPLEMENTASI ETIKA DALAM PELAYANAN PUBLIK DI ERA OTONOMI DAERAH
}

\author{
Ni Wayan Sutiani \\ Fakultas Ilmu Sosial dan Ilmu Politik Universitas Mahendradatta - Denpasar \\ e-mail : sutianiwayan12@gmail.com
}

\begin{abstract}
Abstrak, Pelayanan Publik baik di pusat maupun di daerah masih belum menerapkan nilai-nilai Etika disebabkan adanya pemahaman yang beragam, tidak didukung kebijakan yang memadai, bertentangan dengan nilai budaya lokal, dan bersifat tidak mengikat. Untuk itu pemerintah perlu menetapkan kebijakan mengenai Etika Pelayanan Publik secara terintegrasi dan lebih operasional yang mampu menciptakan kesepahaman dari aparatur pemerintah pusat dan daerah mengenai bentuk kebijakan Etika Pelayanan Publik serta berlaku bagi aparat yang langsung berhubungan dengan masyarakat dan tidak berlaku bagi aparat yang tidak langsung berhubungan dengan masyarakat. Pemerintah perlu menyusun dan mensosialisasikan strategi pengembangan Etika Pelayanan Publik yang operasional dan terintegrasi yang mengakomodasi muatan budaya lokal dan melibatkan seluruh stakeholders pelayanan publik yang ada, baik di kantor - kantor pemerintahan maupun di lembaga swasta
\end{abstract}

Kata Kunci : Implementasi, , Etika, Pelayanan Publik, Era Otonomi Daerah

Abstract, Public services both at the central and regional levels still do not apply Ethical values due to diverse understanding, not supported by adequate policies, contrary to local cultural values, and nonbinding. For this reason, the government needs to establish a policy on public service ethics in an integrated and more operational manner that is able to create an understanding of central and regional government officials regarding the form of Public Service Ethics policy and applies to officials directly related to the community and does not apply to officials who are not directly related to society. The government needs to develop and socialize a strategy for developing operational and integrated Public Service Ethics that accommodates the content of local culture and involves all existing public service stakeholders, both in government offices and in private institutions.

Keywords: Implementation, Ethics, Public Service, Era of Regional Autonomy

\section{A. Pendahuluan}

Saat ini administrasi publik menghadapi tantangan yang cukup banyak sebagai akibat dari adanya tuntutan masyarakat yang semakin beragam, sementara itu sumber daya manusiayang dimiliki sangat terbatas baik dalam jumlah maupun kualitasnya. Oleh sebab ituadministrasi publik dituntut untuk mampu menjawab berbagai tantangan dari persoalanpersoalan yang ada dengan menempuh beragam cara yang dapat dilakukannya. Salah satu cara yang dapat ditempuh guna menjawab tantangan itu adalah dengan melakukan reformasi administrasi publik. Reformasi administrasi publik dilakukan pada berbagai aspek yang melingkupinya. Salah satu aspek yang penting 
diperhatikan dalam proses reformasi administrasi publik adalah aspek etika dalam menjalankan tugas pelayanan kepada masyarakat atau yang lebih dikenal sebagai etika dalam pelayanan publik. Etika dalam pelayanan publik bagi aparatur pemerintah baik di pusat maupun di daerah sering kurang tersentuh dalam kajian-kajian bidang administrasi publik yang dilakukan selama ini, padahal kinerja pelayanan publik sangat ditentukan oleh etika para aparatur yang melaksanakan pelayanan tersebut. Bila aparatur pemerintah memahami dan menerapkan etika dalam memberikan pelayanan secara benar maka kinerja pelayanan diharapkan akan meningkat dan memenuhi keinginan masyarakat yang dilayani. Sebaliknya, apabila etika tersebut tidak dipahami dan dilaksanakan. Secara benar maka kinerja pelayanan menjadi buruk dan akan timbul banyakkomplain dari masyarakat yang dilayani. Realitas di lapangan menunjukkan bahwa kinerja pelayanan publik yang diberikan oleh aparatur pemerintah pusat dan daerah kepada masyarakat belum berakar pada norma-norma etika yang benar. Fenomena lain yang terlihat di lapangan menunjukkan bahwa pola pelayanan aparat pemerintah cenderung sentralistik dan didominasi pendekatan kekuasaan, sehingga kurang peka terhadap perkembangan ekonomi, sosial, budaya dan politik masyarakat, yang seharusnya terbuka, profesional dan akuntabel. Implikasi dari ketidakhadiran (absence) etika dalam pelayanan publik yang paling dirasakan masyarakat adalah perilaku aparatur yang diskriminatif dan tidak efisien.
Pelayanan publik sebagai penggerak utama juga dianggap penting oleh semua aktor dari unsur good governance. Para pejabat publik, unsur-unsur dalam masyarakat sipil dan dunia usaha sama-sama memiliki kepentingan terhadap perbaikan kinerja pelayanan publik. Ada tiga alasan penting yang melatar-belakangi bahwa pembaharuan pelayanan publik dapat mendorong praktik good governance di Indonesia. Pertama, perbaikan kinerja pelayanan publik dinilai penting oleh stakeholders, yaitu pemerintah, warga, dan sektor usaha. Kedua, pelayanan publik adalah ranah dari ketiga unsur governance melakukan interaksi yang sangat intensif. Ketiga, nilainilai yang selama ini mencirikan praktik good governance diterjemahkan secara lebih mudah dan nyata melalui pelayanan publik

Fenomena pelayanan publik oleh birokrasi pemerintahan sarat dengan permasalahan, misalnya prosedur pelayanan yang bertele-tele, ketidakpastian waktu dan harga yang menyebabkan pelayanan menjadi sulit dijangkau secara wajar oleh masyarakat. Hal ini menyebabkan terjadi ketidakpercayaan kepada pemberi pelayanan dalam hal ini birokrasi sehingga masyarakat mencari jalan alternatif untuk mendapatkan pelayanan melalui cara tertentu yaitu dengan memberikan biaya tambahan. Dalam pemberian pelayanan publik, disamping permasalahan diatas, juga tentang cara pelayanan yang diterima oleh masyarakat yang sering melecehkan martabatnya sebagai warga Negara. Masyarakat ditempatkan sebagai klien yang membutuhkan bantuan pejabat birokrasi, sehingga harus tunduk pada ketentuan birokrasi 
dan kemauan dari para pejabatnya. Hal ini terjadi karna budaya yang berkembang dalam birokrasi selama ini bukan budaya pelayanan, tetapi lebih mengarah kepada budaya kekuasaan.

Berdasarkan uraian pada latar belakang mengenai kondisi kinerja pelayanan publik di pusat dan daerah maka dapat dirumuskan permasalahan yang dibahas adalah"Bagaimanakah implementasi etika dalam penyelenggaraan pelayanan publik oleh aparatur pemerintah di pusat dan di daerah saat ini?"

\section{Metode Penelitian}

Penelitian dilakukan dengan metode pencatatan dan dokumentasi. Sumber data Teknik analisis data yang diterapkan pada penelitian ini adalah menggunakan analisis deskriptif.

\section{B. Landasan Teori}

Etika (dalam bahasa Yunani Kuno: "ethikos", berarti "timbul dari kebiasaan") adalah sebuah sesuatu di mana dan bagaimana cabang utama filsafat yang mempelajari nilai atau kualitas yang menjadi studi mengenai standar dan penilaian moral. Etika mencakup analisis dan penerapan konsep seperti benar, salah, baik, buruk, dan tanggung jawab.

Etika dimulai bila manusia merefleksikan unsur-unsur etis dalam pendapat-pendapat spontan kita. Kebutuhan akan refleksi itu akan kita rasakan, antara lain karena pendapat etis kita tidak jarang berbeda dengan pendapat orang lain. Untuk itulah diperlukan etika, yaitu untuk mencari tahu apa yang seharusnya dilakukan oleh manusia.

Menurut Soergarda Poerbakawatja, etika adalah adalah suatu ilmu yang memberikan arahan, acuan, serta pijakan kepada suatu tindakan manusia.

Menurut H. A. Mustafa, pengertian etika adalah ilmu yang menyelidiki terhadap suatu perilaku yang baik dan yang buruk dengan memerhatikan perbuatan manusia sejauh apa yang diketahui oleh akan serta pikiran manusia Menurut Poerwadarminto, arti etika adalah ilmu pengetahuan tentang suatu perilaku atau perbuatan manusia yang dilihat dari sisi baik dan buruknya yang sejauh mana dapat ditentukan oleh akal manusia.

Pelayanan adalah suatu kegiatan atau urutan kegiatan yang terjadi dalam interaksi langsung antar seseorang dengan orang lain atau mesin secara fisik, dan menyediakan kepuasan pelanggan1. Sementara dalam Kamus Besar Bahasa Indonesia dijelaskan pelayana sebagai hal, cara atau hasil pekerjaan melayani. Sedangkan melayani adalah menyuguhi (orang dengan makanan atau minuman; menyediakan keperluan orang; mengiyakan, menerima; menggunakan).

Menurut Undang-undang No. 25 Tahun 2009, Pelayanan publik adalah kegiatan atau rangkaian dalam rangka pemenuhan kebutuhan pelayanan sesuai dengan peraturan perundangundangan bagi setiap warga Negara dan penduduk atas barang, jasa, dan/atau pelayanan 
administratif yang disediakan oleh penyelenggara publik.

Sementara itu istilah publik berasal dari bahasa inggris public yang berarti umum, masyarakat, negara. Kata publik sebenarnya sudah diterima menjadi bahasa Indonesia baku menjadi publik yang berarti umum, orang banyak, ramai. Padanan kata yang tepat digunakan adalah praja yang sebenarnya bermakna rakyat sehingga lahir istilah pamong praja yang berarti pemerintah yang melayani kepentingan seluruh rakyat ${ }^{2}$.

Oleh karena itu pelayanan publik diartikan sebagai setiap kegiatan yang dilakukan oleh pemerintah terhadap sejumlah manusia yang memiliki setiap kegiatan yang menguntungkan dalam suatu kumpulan atau kesatuan, dan menawarkan kepuasan meskipun hasilnya tidak terikat pada suatu produk secara fisik.

Lijan Poltak Sinambela mengartikan pelayanan publik sebagai pemberian layanan (melayani) keperluan orang atau masyarakat yang mempunyai kepentingan pada organisasi itu sesuai dengan aturan pokok yang telah ditetapkan. Pelayanan publik adalah pemenuhan keinginan dan kebutuhan masyarakat pada penyelenggaraan negara ${ }^{3}$. Negara didirikan oleh publik atau masyarakat tentu saja dengan tujuan agar dapat meningkatkan kesejahteraan masyarakat. Pada hakekatnya negara dalam hal ini birokrasi haruslah dapat memenuhi kebutuhan masyarakat. Kebutuhan dalam hal ini bukanlah kebutuhan secara individual akan tetapi

2 L.P. Sinambela, Reformasi Pelayanan Publik, Jakarta, Bumi Aksara, 2010, hlm 5 berbagai kebutuhan yang sesungguhnya diharapkan oleh masyarakat.

Tujuan pelayanan publik adalah memuaskan dan bisa sesuai dengan keinginan masyarakat atau pelayanan pada umumnya ${ }^{4}$. Untuk mencapai hal ini diperlukan kualitas pelayanan yang sesuai dengan kebutuhan dan keinginan masyarakat. Berdasarkan Keputusan Menteri Pendayagunaan Aparatur Negara No 62 tahun 2003 tentang penyelenggaraan pelayanan publik setidaknya mengandung sendi-sendi :

1. Kesederhanaan, dalam arti prosedur atau tata cara pelayanan diselenggarakan secara cepat, tidak berbelit-belit, mudah dipahami dan mudah dilaksanakan.

2. Kejelasan yang mencakup :

a.Rincian biaya atau tarif pelayanan publik.

b.Prosedur/tata cara umum, baik teknis maupun administratif.

3. Kepastian waktu, yaitu pelaksanaan pelayanan publik harus dapat diselesaikan dalam kurun waktu yang telah ditentukan.

4. Kemudahan akses, yaitu bahwa tempat dan lokasi serta sarana pelayanan yang memadai, mudah dijangkau oleh masyarakat, dan dapat memanfaatkan teknologi telekomunikasi dan informatika.

5. Kedisiplinan, kesopanan dan keramahan, yakni memberi pelayanan harus bersikap disiplin, sopan dan santun, ramah serta memberikan pelayanan dengan ikhlas.

6. Kelengkapan sarana dan prasarana kerja, peralatan kerja dan pendukung lainnya

3 Opcit, L.P Sinambela, Hlm 5 4 opcit, L.P Sinambela, Hlm 6 
yang memadai termasuk penyediaan sarana teknologi telekomunikasi dan informatika

\section{Pembahasan}

Faktor yang mempengaruhi Implementasi Etika dalam Pelayanan Publik di Indonesia Saat Ini pada instansi-instansi pemerintah di Indonesia menurut penulis dapat diidentifikasi sebagai berikut :

1. Dalam praktek penyelenggaraan pelayanan publik di instansi-instansi pemerintah khususnya yang menyelenggarakan pelayanan secara langsung kepada masyarakat baik individu maupun badan, petugas-petugas pemberi pelayanan memiliki dua sikap yang berbeda, yaitu sikap yang absolutis dan sikap yang realitis, Sikap absolutis muncul berkaitan dengan keyakinan petugas yang ber sangkutan bahwa dalam pelayananpublik dikenal norma-norma yang bersifat absolute yang cenderung diterima semua tempatdan bersifat universal (universal rules). Petugas yang memiliki sikap seperti ini akanmelaksanakan tugasnya dengan sebaikbaiknya berdasarkan nilai-nilai yang diyakininya baikdan bersifat umum. Petugas yang termasuk kelompok ini adalah petugas yang memilikikeyakinan profesi, keyakinan agama dan nilai-nilai kemanusiaan yang kuat. Petugas yangmemiliki sikap absolutis ini akan bersikap tegas dan cenderung kaku (tidak memiliki toleransiterhadap penyimpangan terhadap prosedur yang berlaku dan menyalahi nilai-nilai universalyang diyakininya). Sikap realistis muncul pada petugas yang memiliki keyakinan yang berbedadengan keyakinan absolutis. Mereka beranggapan bahwa kebenaran itu bersifat relatif sesuaidengan kondisi yang ada. Dengan kata lain bahwa kebenaran itu memiliki konsekuensi yangbaik berdasarkan kenyataan lapangan. Petugas yang memiliki keyakinan seperti iniberanggapan bahwa norma yang bersifat universal itu belum tentu baik apabila tidak sesuaidengan kondisi yang ada. Dengan demikian akan terjadi kecenderungan untuk mengambilkeputusan yang dianggapnya benar pada saat melaksanakan tugasnya sesuai dengan kondisiyang ada akan lebih sering terjadi. Hal inilah yang membuka celah terjadinya "kerjasama" yangmenguntungkan dengan "penerima layanan" apabila petugas tidak memperhatikan aturan main yang berlaku.

2. Belum ada kebenaran yang hakiki terhadap Etika dalam penyelenggaraan pelayanan publik baik bagi petugas pemberi layanan maupun masyarakat sebagai penerimalayanan. Kebenaran dalam beretika dalam penyelenggaraan pelayanan publik masihdipengaruhi sikap yangdidasarkan pada keyakinan pemberi pelayanan terhadap etikapelayanan publik dan keyakinan masyarakat penerima layanan publik. Kondisi ini dapatdiketahui dari kenyataan di lapangan bahwa "kebenaran dalam beretika”tergantung darikepentingan petugas dan kepentingan individu masyarakat penerima layanan. Apabila keduakepentingan terakomodasi dalam proses pelayanan maka pelayanan tersebut dianggap telah memenuhi "kebenaran etika". Padahal dapat saja "kebenaran dalam 
beretika" tersebut melanggar rasa keadilan terhadap anggota masyarakat yang lain atau bahkan masyarakatpenerima layanan secara umum. Kondisi ini muncul karena pelanggaran "etika" hanya memiliki sanksi sosial saja yang sering kali tidak efektif untuk mengubah tingkah laku melanggar daripetugas pemberi layanan ataupun masyarakat penerima layanan,

3. Terjadi tumpang tindih terhadap implementasi keempat tingkatan etika dalam proses penyelenggaraan pelayanan publik kepada masyarakat. Etika pelayanan publik terdiri atas empat tingkatan, yaitu a) etika individu, b) etika profesi, c) etika organisasi, dan d) etika sosial. Etika individu atau moral pribadi yaitu etika yang memberikan tuntunan mengenai baik atau buruk yang dipengaruhi orang tua, keyakinan agama, budaya, adat istiadat, dan pengalaman masa lalu. Biasanya etika ini terbentuk sebelum menjadi pegawai negeri (petugas penyelenggara pelayanan publik). Etika profesi adalah serangkaian norma atau aturan yang menuntun perilaku kalangan profesi tertentu salah satunya adalah pegawai negeri yang menyelenggarakan pelayanan kepada masyarakat. Etika ini terbentuk pada saat menjalankan atau menduduki jabatan tertentu atau dengan kata lain terbentuk pada saat menjadi pegawai negeri. Etika organisasi adalah serangkaian aturan dan norma yang bersifat formal dan tidak formal yang menuntun perilaku dan tindakan anggota organisasi yang bersangkutan. Pegawai negeri sebagai penyelenggara pelayanan publik juga terikat dengan organisasi tempat bekerja. Etika organisasi akan mewarnai perilaku yang dimiliki pegawai negeri yang merupakan anggota organisasi temapat ia bekerja. Etika sosial adalah norma-norma yang menuntun perilaku dan tindakan anggota masyarakat agar keutuhan kelompok dan anggota masyarakat selalu terjaga atau terpelihara. Pegawai negeri sebagai petugas penyelenggara pelayanan publik juga merupakan anggota masyarakat yang tidak akan lepas dari pengaruh kehidupan masyarakat disekelilingnya yang dapat berupa budaya, tradisi, pola pikir. Etika sosial akan mempengaruhi petugas penyelenggara pelayanan publik baik disadari ataupun tidak. Faktor penerapan keempat tingkatan etika pelayanan publik tersebut seringkali menimbulkan kebingungan para petugas penyelenggara pelayanan publik. Kebingungan itu menyangkut penentuan prioritas keempat tingkatan etika tersebut dalam penyelenggaraan pelayanan disesuaikan dengan kondisi saat pelayanan tersebut berlangsung. Apabila kondisi berbeda maka penentuan prioritas keempat tingkatan etika pelayanan publik pun akan berbeda yang mengakibatkan keputusan yang diambil akan berbeda pula. Misalnya, petugas pelayanan publik menghadapi saudaranya yang menjadi penerima layanan tentu etika individu akan lebih dominan, sebaliknya bila yang dihadapi adalah atasannya yang menjadi penerima layanan tentu etika organisasi akan lebih dominan. Kondisi seperti inilah yang selalu "menghantui" 
petugas penyelenggara pelayanan publik pada saat bertugas

4. Keputusan mengenai etika yang diberlakukan di dalam suatuinstitusi pelayanan publik tergantung pada atasan yang berwenang. Petugas penyeleng garapelayanan publik tidak terlepas dari pengaruh etika organisasi tempat mereka bekerja. Sebenarnya etika penyelenggaraan pelayanan merupakan manifestasi dari aturan organisasi yang berlaku.Dalam organisasi formal aturan yang berlaku adalah keputusan pejabat yang berwenang.Dengan demikian maka etika penyelenggaraan pelayanan publik merupakan perwujudan darikeputusan pejabat yang berwenang. Oleh sebab itu maka keputusan-keputusan yang diambiloleh petugas penyelenggara pelayanan identik dengan keputusan pejabat yang berwenang.Misalkan keputusan pelayanan kesehatan di suatu Puskesmas identik dengan keputusanKepala Puskesmas yang bersangkutan.

\section{Pembahasan Implementasi Etika}

Kondisi Implementasi Etika dalam Pelayanan Publik, dengan bertitik tolak pada faktor yang mempengaruhi implementasi etika dalam penyelenggaraan pelayanan publik makadapat dirumuskan analisis kondisi implementasi etika dalam pelayanan publik di pusat dan di daerah adalah sebagai berikut

1. Dalam penyelenggaraan pelayanan publik masih belum didukung dengan kode etik profesi yang memadai. Penyelenggaraan pelayanan publikmencakup berbagai profesi sesuai dengan jenis pelayanan, misalnya pelayanan di bidangkesehatan menyangkut profesi dokter dan profesi perawat (tenaga medis), profesi apoteker,dan profesi lainnya. Berdasarkan pengamatan hasil telaah literatur dan pengamatan lapangandiketahui bahwa masih terbatasnya kode etik profesi yang dimiliki oleh petugas yangmelaksanakan pelayanan publik atau dengan kata lain masih banyak profesi yang belummemiliki kode etik dan hanya beberapa profesi yang memiliki kode etik seperti dokter,akuntan, pengacara. Meskipun secara umum para petugas penyelenggara pelayanan publiksebagai pegawai negeri telah memiliki kode etik pegawai negeri. Kode etik pegawai negerimemiliki sifat yang umum (general) sehingga belum dapat dijadikan acuan bagi petugaspenyelenggara pelayanan yang memiliki profesi yang khusus (khas) yang bersifat teknis. Olehsebab itu kode etik pegawai negeri perlu didukung dengan kode etik profesi. Kenyataan dilapangan menunjukkan bahwa narasumber di lokasi penelitian menekankan pentingnya kodeetik profesi dalam rangka mendukung penyelenggaraan pelayanan publik. Misalnya narasumber dari Sulawesi Tengah menyatakan bahwa perlu memberikan memberikan "bekal etika"(etika profesi) bagi para petugas yang melaksanakan pelayanan publik disamping aturan teknisdalam penyelenggaraan tugas pelayanan yang menjadi tanggung jawabnya. Tak jauh berbeda narasumber dari Papua menyatakan bahwa kondisi yang ada saat ini adalah PNS belummemiliki 
Code Of Conduct dan tak diikuti dengan glorifikasi (keakuan) atau sejenis denganotoriter dalam demokrasi. Aparat terhanyut dalam "The Shadow Of System" (kekuatan sistembayangan) yang mengikis budaya positif yang dimiliki aparatur yang bersangkutan. Hal senadadikemukakan nara sumber dari Gorontalo yang menyatakan bahwa berkaitan dengan etika, diIndonesia, baik di pusat maupun di daerah tidak ada atau kurangnya kode etik yang menjadidasar birokrasi/aparatur untuk bekerja dalam rangka pelayanan pada masyarakat etika yangperlu diterapkan dalam berorganisasi adalah etika individu, etika organisasi dan etika profesi.Etika individu menentukan baik atau buruk perilaku orang perorangan dalam hubungannyadengan orang lain. Etika organisasi berfungsi menetapkan parameter dan merinci kewajiban kewajiban organisasi itu sendiri serta menggariskan konteks tempat keputusan-keputusan etikaperorangan itu dibentuk. Etika organisasi sebagai aturan yang dicerminkan dalam strukturorganisasi dan fungsi-fungsi serta prosedur, termasuk di dalamnya sistem insentif, disinsentif dan sanksi-sanksi berdasarkan aturan. Etika profesional berlaku dalam suatu kerangka yangditerima oleh semua yang secara hukum atau secara moral mengikat mereka dalam kelompokprofesi yang bersangkutan. Ketiga macam etika tersebut idealnya dapat diikuti, dipatuhi dan dijadikan pedoman, pegangan, referensi seseorang dalam melakukan hubungan dengan oranglain dalam organisasi, menjalankan tugas/profesinya.
Sementara itu terkait dengan etikaprofesi, ada beberapa kalangan yang masih memiliki sikap yang menyakini bahwa meskipunbelum ada kode etik petugas penyelenggara pelayanan publik (kode etik profesi) tetapi pelayanan publik masih dapat dilaksanakan dengan rambu-rambu nilainilai agama dan nilai-nilaiPancasila. Kenyataan di lapangan menunjukkan bahwa ketidakadaan kode etikmenciptakan peluang bagi petugas untuk mengabaikan etika pelayanan publik atau dengankata lain tidak ada alat kontrol perilaku petugas penyelenggara pelayanan publik. Kisah yang menarik mengenai pentingnya kode etik profesi terjadi di Sulawesi Tengah tepatnya diKabupaten Morowali dan Kabupaten Parigimoto. Kabupaten Morowali ini dipimpin olehseorang Bupati yang (dianggap) tidak memiliki kemapuan. Waktunya sebagian besardihabiskan di Jakarta, keberadaan di kantor hanya 3 hari dalam seminggu pada jam 6 subuhdan jam 6 sore. Dengan kondisi ini maka pelayanan publik menjadi "lumpuh". Disamping ituBupati tidak memiliki hubungan baik sebagai Wakil Bupati yang merupakan wakilnya bila dia berhalangan. Kondisi ini ditengarai merupakan hasil dari proses rekrutmen dari sistem yangtidak baik (garbage in garbage out). Kondisi yang terjadi di Morowali bertentangan dengankondisi yang terjadi di Kabupaten Parigimoto. Di Kabupaten ini memiliki Bupati yang dianggapmemiliki kemampuan. Sebagai ilustrasi Bupati memberikan kemudahan akses kepada nelayandalam 
berhubungan dengan Bank, karena apabila nelayan langsung berhubungan denganpihak Perbankan akan mengalami kesulitan. Kisah di atas menunjukkan bahwa dengan Ketidakadaan kode etik profesi sebagai seorang Bupati (Penyelenggara pelayanan publik)maka Bupati bisa berperilaku semaunya sendiri tanpa mempedulikan tugasnya kepadamasyarakat seperti yang terjadi di Kabupaten Morowali, ataupun sebaliknya Bupati dapatberbuat banyak untuk kepentingan masyarakatnya seperti yang terjadi di Kabupaten Parigimoto.

2. Belum terimplementasikan secara optimal kebijakan pelayanan publik yangmemuat kode etik penyelenggaraan pelayanan publik. Meskipun kebijakan pelayanan publiktelah diterbitkan seperti Inpres No. 1 Tahun 1995 tentang Perbaikan dan Peningkatan MutuPelayanan Aparatur Pemerintah kepada Masyarakat dan KepmenPAN No.63/KEP/M.PAN/7/2003 Tanggal 10 Juli 2003 tentang Pedoman Umum PenyelenggaraanPelayanan Publik namun belum terlaksana dengan baik di lapangan. Padahal yang terpentingadalah pengimplementasiannya di lapangan. Kendala yang ditemui adalah kebijakan tersebutbelum sepenuhnya ditindaklanjuti dengan kebijakan yang bersifat operasional oleh aparat baikdi tingkat pusat maupun di daerah. Bukti di lapangan menunjukkan bahwa terdapat variasibentuk dan muatan kebijakan mengenai pelayanan publik. Lebih-lebih belum adakesepahaman apakah kebijakan etika pelayanan publik dibuat dalam format hukum positif atautidak. Nara sumber dari Sulawesi
Tengah menyatakan bahwa Ada beberapa kalangan yangselalu mengkaitkan antara etika dengan hukum (etika diidentikkan dengan hukum). Tetapi adakalangan yang membedakan antara etika dengan hukum. Kalangan yang terakhir berpendapatbahwa etika merupakan sesuatu yang melekat dari diri seseorang bukan sesuatu yang dipaksakan dari luar (Norma). Kalangan ini berpendapat bahwa norma bukan hukum dannorma tidak memiliki sanksi hukum...Etika tata pemerintahan yang baik (termasuk di dalamnyaetika pelayanan publik) tidak selalu di"positifkan" (dijadikan aturan hukum yang memuat sanksibagi yang melanggar). Nara sumber dari Papua menyatakan bahwa etika memiliki batasberupa ruang dan waktu. Etika sebagai norma hukum tidak mengedepan unsur sanksi hukumyang bersifat nasional. Sanksi yang diberlakukan bersifat sanksi sosial yang dilakukan olehmasyarakat. Memang pada kenyataannya sanksi sosial yang diberikan pada pelanggaran etikabelum tersosialisasikan dengan baik dan tak mampu memberikan dampak menghukum yangefektif. Nara sumber dari Gorontalo menyatakan bahwa etika adalah seperangkat nilai yangdapat dijadikan pedoman, referensi, acuan, dan penuntun apa yang harus dilakukan dalam menjalankan tugas. Dengan demikian etika merupakan standar yang berfungsi untuk menilaiapakah sifat, perilaku, tindakan atau sepak terjangnya dalam menjalankan tugas dinilai baikatau buruk. Dengan belum adanya kesepahaman mengenai etika pelayanan publik inimengakibatkan kesulitan dalam pengimplementasiannya di lapangan. Padahal dengan belumadanya implementasi di lapangan 
berarti kegiatan penilaian akan sulit dilakukan yang akhirnya pengembangan dan penyesuaian kode etik pelayanan publik terhadap keadaan danperubahan zaman akan sulit dilaksanakan, 3) berdasarkan hasil pengamatan di lapangan diketahui bahwa kesadaran untuk beretika dalam penyelenggaraan pelayanan publik olehpetugas penyelenggara dan oleh masyarakat penerima pelayanan publik masih rendah. Mereka masih cenderung berorientasi pada kepentingan pribadi (kepentingan sendiri). Disamping masih kurangnya pemahaman mereka terhadap etika pelayanan publik. Bukti dilapangan menunjukkan di tiga lokasi penelitian menunjukkan kecenderungan yang samameskipun dengan alasan yang berbeda-beda. Sementara ini pemahaman etika pelayanan publik selalu dikaitkan dengankegiatan yang bersifat protokoler sehingga sering kali dipahami sebagai nilainilai yang bersifatsimbolik. Dengan pemahaman seperti ini maka etika pelayanan publik merupakan kebijakanyang bersifat tidak menyeluruh. Etika pelayanan publik hanya dilaksanakan oleh aparat yanglangsung melaksanakan kegiatan pelayanan terhadap masyarakat dan bukan oleh aparatdaerah yang tidak langsung berhubungan dengan masyarakat... aparat pemerintah daerah"melayani masyarakat tidak dengan sepenuh hati" artinya bahwa dalam memberikanpelayanan kepada masyarakat tidak secara totalitas tetapi hanya sekedarnya saja. Fenomenaini semakin kuat pada era otonomi dan bahkan ada yang beranggapan "Telah Hilangnya Profesionalisme" aparat dalam melayani masyarakat. Kondisi inilah yang menimbulkan kondisi yang menyimpang (deviation of behavior). Pendapatan yangkurang dan kesejahteraan yang tidak mendukung menyebabkan kinerja yang tidak optimal.Pada umumnya pada hari keduapuluh (tanggal 20 setiap bulan) beras yang dimiliki telah habisdengan demikian pegawai yang bersangkutan akan berusaha untuk mencari tambahan gunamenutup kekurangan tersebut dengan cara mencari pekerjaan sambilan ataupun berupayauntuk mendapatkan tambahan penghasilan di kantor (cikal bakal perilaku menyimpang). Narasumber dari Gorontalo menyatakan bahwa permasalahan yang muncul dalam proses etika, diantaranya adalah belum adanya kesadaran beretika dalam pelayanan publik baik di pusatmaupun di daerah dan kurangnya sosialisasi pada masyarakat. Aparat/pegawai atau staf yangberada pada front office tidak mengerti akan tupoksinya sehingga mereka bekerja dengankemauannya sendiri. Adanya sikap tidak perduli dari aparat dan masyarakat terhadappentingnya etika dalam pelayanan publik. Berdasarkan pendapat narasumber di lokasipenelitian bahwa kesadaran beretika dalam penyelenggaraan pelayanan publik dipengaruhioleh kemampuan aparat (petugas penyelenggara pelayanan publik) dan tingkat kesejahteraanyang dimilikinya. Terkait dengan pemahaman terhadap etika pelayanan publik khususnya yangmenyangkut penentuan prioritas dalam penggunaan tingkatan etika di lokasi kajian dapat digambarkan menurut pendapat narasumber berikut ini. Nara sumber dari Sulawesi Tengah menyatakan bahwa Pelayanan publik memiliki dua sisi, yaitu: 
aturan dan etika. Aturan dalam pelayanan publik membawa konsekuensi pada kontra prestasi, artinya apabila aturan dilaksanakan secara baik maka akan diberikan penghargaan terhadap aparat yang bersangkutan, sedangkan etika merupakan norma dalam memberikan pelayanaan (norma melayani). Etika dalam penyelenggaraan pelayanan publik di tingkat nasional (bersifat universal) sedangkan perbedaan yang muncul merupakan dimensi kultural yang ada padalokasi penyelenggaraan pelayanan. Etika dalampelayanan publik menyangkut dua aspek utama, yaitu: aspek internal dan aspek eksternal. Aspek internal menyangkut kondisi individual aparat yang bersangkutan. Aspek eksternalmenyangkut kondisi lingkungan aparat yang terdiri dari: a) tradisi dan budaya, b) pendapatan, dan c) kualitas pegawai yang bersangkutan. Tradisi dan budaya aparat dipengaruhi olehkondisi tempat bekerja. Tradisi dan budaya ini tumbuh dalam birokrasi tempat aparat itubekerja sejak rekruitmen awal. Pada saat rekruitmen pegawai biasanya didasarkan padaupaya untuk mengisi pekerjaan yang lowong dalam rangka mengurangi pengangguran. Tradisiinilah yang menyebabkan pegawai tidak dapat berkinerja dengan baik dan bahkanmenimbulkan prilaku yang menyimpang atau sering disebut sebagai pathologi birokrasi. Etikadalam penyelenggaraan pelayanan publik terdiri dari dua kelompok, yaitu Etika birokrasi danEtika individu. Etika birokrasi terbentuk karena adanya proses interaksi organisasi sedangkanetika individu terbentuk karena pengaruh keluarga dan dogma yang dimiliki oleh pegawai yangbersangkutan. Etika dalam penyelenggaraan pelayanan publik akan dipatuhi oleh aparat yangmemiliki kesempatan untuk mempraktekkannya dalam kesehariannya sebagai seorangaparatur yang menyelenggarakan pelayanan kepada masyarakat. Kesempatan yang dimilikiadalah kondisi yang mendukung bagi aparat yang bersangkutan menerapkan etika yaitu:a) memiliki kinerja yang memadai, b) daya tanggap yang dimiliki pegawai, dan c) iklim yangmendukung akuntabilitas. Sistem kehidupan bermasyarakat menciptakan budaya, daerahsebagai sistem nilai yang terbentuk dari keterpaduan antara norma-norma yang telah adadalam masyarakat dan norma baru yang mempengaruhinya seperti norma-norma agama yangberkembang di daerah tersebut. Dalam perkembangan selanjutnya etnis-etnis tertentu mengagungkan suatu sistem nilai tertentu yang mempengaruhi proses penyelenggaraan pemerintahan yang adakalanya tidak bersifat "fair". Nara sumber dari Gorontalo menyatakanbahwa Kentalnya pengaruh budaya feodalistik yang masih ada pada sebagaian masyarakat. Hal tersebut banyak berpengaruh pada pelayanan kepada masyarakat, sebagai contoh, diwilayah-wilayah tertentu di Gorontalo ada pelayanan khusus kepada margamarga tertentu. Selanjutnya dalam rangka peningkatan kesadaran aparatur daerah dalam penyelenggaraanetika dalam pelayanan publik dapat ditempuh dengan meningkatkan kedewasaan aparaturdaerah dalam beretika. Untuk itu diperlukan nilai-nilai bersifat universal yang mengakomodasi nilai-nilai budaya lokal yang positif agar mampu mendekatkan aparatur daerah terhadap perilaku 
positif yang sehari-hari mereka hadapi dalam penyelenggaraan pelayanan publikyang akhirnya akan membangkitkan kesadaran beretika. Secara umum nilai-nilai universalyang dapat dikembangkan adalah: integritas, kebenaran, kejujuran, ketabahan, respek,menaruh perhatian, keramahan, cepat tanggap, mengutamakan kepentingan publik di ataskepentingan lain, bekerja profesional, pengembangan profesionalisme, komunikasi terbuka dantransparansi, kreativitas, dedikasi, kasih sayang, penggunaan keleluasaan untuk kepentingan publik, beri perlindungan terhadap informasi yang sepatutnya dirahasiakan. Sedangkan nilai nilai lokal yang dapat diakomodasi adalah: senang melihat orang lain senang untuk budayaSulawesi Tengah), solidaritas sosial, transparansi, kejujuran, teguh prinsip, keterusterangan, pengambilan keputusan (kein-kein karkara), menghargai tuan rumah, untuk budaya Papua, memberi kepuasan kepada tamu untuk budaya Gorontalo, 4) Belum ada ukuran yang jelas danpasti dalam menilai etika pelayanan publik. Dari masing-masing daerah kajian belumditemukan ukuran yang jelas dan pasti terhadap etika pelayanan publik. Hal ini disebabkan oleh ketidakadaan/keterbatasan nilai etika yang dimiliki, contoh konkritnya adalah nilaimoralitas terhadap uang. Disamping itu adanya kecenderungan mengutamakan kepentingan tertentu tanpa memperhatikan konteks (kondisi yang ada) pelayanan publik yang diberikan. Pegawai negeri sebagai salah satu penyelenggara pelayanan publik dan sekaligus anggotaorganisasi pemerintah (birokrasi) tidak dapat lepas dari kepentingan organisasi yang merupakan manifestasi dari keputusan pimpinan yang berwenang dari organisasi yang bersangkutan. Karena tidak adanya ukutan yang jelas dan pasti dari etika pelayanan publikyang diberikan maka petugas akan cenderung mengutamakan (mengamankan) keputusan pimpinan organisasi. Kuatnya “imperatif" terhadap kekuasaan yang berarti bahwa etika pelayanan publik merupakan manifestasi dari perintah atasan kepada bawahan bukan merupakan kesadaran dari aparatyang bersangkutan. Disamping itu adanya ego sektoral dari institusi tertentu yang menganggap bahwa satu institusi lebih baik dari institusi yang lain dalam proses penyelenggaraan pelayanan publik. Fenomena yang lain adalah adanya ikatan etnis lokal yang kuat menyebabkan penyelenggaraan pelayanan publik lebih mengutamakan etnis tertentu, narasumber dari Gorontalo menyatakan bahwa kentalnya pengaruh budaya feodalistik yang masihada pada sebagian masyarakat. Hal tersebut banyak berpengaruh pada pelayanan kepada masyarakat, sebagai contoh, di wilayahwilayah tertentu di Gorontalo ada pelayanan khususkepada marga-marga tertentu. Ketidakadaan ukuran yang jelas dan pasti terhadap etika mengakibatkan mekanisme kontrol yang lemah, sehingga "tidak ada" perlindungan terhadappengadu terhadap pelanggaran kode etik penyelenggaraan pelayanan. Yang lebih parah lagipengadu jangankan mendapatkan "imbalan" justru dianggap tidak terpuji, terkutuk dan dalamposisi yang terancam. Kondisi ini menyebabkan birokrasi sebagai penyelenggara 
pelayananpublik menjadi "bisu dan tuli" seperti ungkapan nara sumber dari Sulawesi Tengah yang menyatakan bahwa birokrasi "buta dan tuli" yang berarti bahwa birokrasi sebagai unsur penyelenggara pelayanan publik dari pemerintah tidak tanggap terhadap kebutuhan masyarakat yang dilayani dan tidak mendengar keluhan-keluhan ketidakpuasan dari masyarakat terhadap pelayanan yang diberikan dari aparat pemerintah daerah "melayani masyarakat tidak dengan sepenuh hati" artinya bahwa dalam memberikan pelayanan kepada masyarakat tidak secara totalitas tetapi hanya sekedarnya saja. Fenomena ini semakin kuat pada era otonomi dan bahkan ada yang beranggapan "telah hilangnya profesionalisme" aparat dalam melayani masyarakat. Ketiadaan dialog antar stakeholer pelayanan publik makin memperparah kondisi pelayanan publik saat ini, karena masing-masing aktor pelayanan publik bergerak dengan aturan main yang berbedabeda dan dengan kepentingan sendiri-sendiri dalam kondisi ketidakjelasan dan ketidak pastian ukuran etika pelayanan publik

\section{Penutup}

Dari uraian pembahasan mengenai Implementasi Etika dalam Penyelenggaraan Pelayanan Publik di Indonesia dapat disimpulkan bahwa penyelenggaraan pelayanan publik baik di pusat maupun di daerah masih belum menerapkan nilai-nilai etika disebabkan adanya pemahaman yang beragam, tidak didukung kebijakan yang memadai, bertentangan dengan nilai budaya lokal, dan bersifat tidak mengikat. Belum ada strategi implementasi yang baku dan memadai dalam pengembanganetika pelayanan publik sehingga etika pelayanan publik yang ada belum mendukung peningkatan kinerja aparatur di pusat dan di daerah. Berdasarkan pembahasan mengenai Implementasi Etika dalam Penyelenggaraan Pelayanan Publik di Indonesia dapat dirumuskan rkomendasi yang sekiranya dapat dijadikan bahan masukan dan pertimbangan bagipengambil kebijakan khususnya dalam menentukan kebijakan implementasi etika dalam pelayanan publik.

\section{Saran}

1. Pemerintah perlu menetapkan kebijakan mengenai etika pelayanan publik secara terintegrasi dan lebih operasional yang mampu menciptakan kesepahaman dari aparatur pemerintah pusat dan daerah mengenai bentuk kebijakan etika pelayanan publik serta berlaku bagi aparat yang langsung berhubungan dengan masyarakat dan tidak berlaku bagi aparat yang tidak langsung berhubungan dengan masyarakat.

2. Pemerintah perlu menyusun dan mensosialisasikan strategi pengembangan etika pelayanan publik yang dapat mengakomodasi muatan budaya lokal dan melibatkan seluruh stakeholders pelayanan publik yang ada.

3. Penyusun kebijakan perlu mengakomodasi nilai-nilai etika pelayanan publik dalam setiap produk kebijakan penyelenggaraan negara yang ditetapkan khususnya yang menyangkut sumber daya aparatur.

\section{DAFTAR PUSTAKA}

Abdussamad, Zamroni, (2005), Pokok-Pokok Pikiran Pengembangan Etika Dalam Pelayanan Publik, Universitas Gorontalo; Albow, Martin, (1989). 
Arief, Himawan, (2003), Sukses Bukan Luck Tetapi Direncanakan, Jakarta: PT Pustaka Binaman, Pressindo;

Bartens, K. (2000), Etika. Seri Filsafat Atma Jaya; 15, Jakarta: PenerbitPT. Gramedia Pustaka Utama Bauw, Lily dan Yusak E. Reba, (2005), Etika dalam Pelayanan Publik, Fakultas Hukum Universitas Cendrawasih; Denhardt, Kathryn G., (1988).

Gafar, Afan, (1999), Politik Indonesia, Transisi Menuju Demokrasi, Yogyakarta: Pustaka Belajar; Grindle, Merite S ed, (1980).

Instruksi Presiden Republik Indonesia Nomor 1 Tahun 1995 Tentang Perbaikan Dan Peningkatan Mutu Pelayanan Aparatur Pemerintah Kepada Masyarakat tertanggal 6 Maret 1995; Keban, Yeremias T., (2005),

Etika Pelayanan Publik: Pergeseran Paradigma, Dilema dan Impilaksinya bagi Pelayanan Publik di Indonesia, FISIPOL Universitas Gadjah Mada.
Keputusan Menteri Pendayagunaan Aparatur Negara Nomor 63/Kep/M.Pan/7/2003 Tahun 2003 Tanggal 10 Juli 2003 Tentang Pedoman Umum Penyelenggaraan Pelayanan Publik. Komisi Ombudsman, (2005).

Pedoman Dasar Dan Etika Komisi Ombudsman Nasional; Lembaga Administrasi Negara, (2004), Etika dalam Penyelenggaraan Negara-Tinjauan atas strategi pengembangannya dalam penyelenggaraan pemerintahan; Samudra (1994), Kebijakan Publik : Proses dan Analisa Intermedia, Jakarta, Simmon, (1978).

Public administration and Implementation, Prentice Hall International Inc, London.

Sudana, I Wayan, (2005), Lemahnya Etika Pelayanan Publik, Fisipol Universitas Warmadewa Denpasar Sugiyanto, (2004). 